\title{
STRATEGIC SUSTAINABILITY MANAGEMENT IN THE EVENT SECTOR
}

\author{
MARK WICKHAM, TIMOTHY DONNELLY, AND LINDA FRENCH
}

Tasmanian School of Business \& Economics, University of Tasmania, Hobart, Tasmania, Australia

\begin{abstract}
Although the Triple Bottom Line approach has underpinned significant progress in our knowledge of sustainability in the event sector, scholars have recently criticized this approach for its overemphasis on reporting outcomes and have called for a new conceptualization that accounts for strategic inputs in order to maintain progress towards greater sustainability knowledge and performance. This research utilizes a widely-accepted strategic framework, the Resource-Based View of the Firm, as a lens to gain insight into the inputs of strategic sustainability management in the events sector. Therefore, the research question to be addressed is: What resources and capabilities are associated with best-practice strategic sustainability management in the event sector? In order to address this question, a qualitative content analysis of the websites of 10 international music events that have achieved best-practice sustainability accreditation from the Greener Festival Awards organization was conducted. Analysis of the data detected 11 resources and inferred 14 capabilities associated with best-practice strategic sustainability management in the event sector. The data also demonstrated the interrelationships that exist between the sample events' resource deployment and suggests that reputational capital plays a key role (both as a desirable outcome of, but also a critical resource input into) in best-practice sustainability management. Lastly, this article concludes with a range of research opportunities going forward relating to sustainability management in the event sector.
\end{abstract}

Key words: Event sustainability; Strategic management; Resource-based view

Introduction

The significance and growth of events (both in terms of their economic and social development potential) has been well documented in the literature over the past two decades (see Getz, 1997, 2017; Kwiatkowski \& Oklevik, 2017). Coinciding with this has been increasing interest as to what constitutes best-practice sustainability management in the event context; at its core, this interest has focused on studying the mechanisms by which the positive economic and social impacts of events can be maximized while damage to the environment is simultaneously minimized (see Gibson \& Wong, 2011; Mair \& Laing, 2013). Therefore, research into event sustainability management has played out prominently in terms of the Triple Bottom Line (TBL) (i.e., on economic, social, and environmental

Address correspondence to Mark Wickham, Ph.D., Senior Lecturer, Tasmanian School of Business \& Economics, University of Tasmania, Locked Bag 84, Hobart, Tasmania 7001, Australia. Tel: +61 36226 2159; E-mail: Mark.Wickham@utas.edu.au 
issues - see Andersson \& Lundberg, 2013; Collins \& Cooper, 2017). Although the TBL approach to sustainability management and academic research has underpinned considerable progress in terms of event sustainability knowledge and performance management, there is recognition that new conceptualizations are needed to maintain momentum in this regard (see Milne \& Gray, 2012; Werner et al., 2017). For example, Rambaud and Richard (2015) criticized the conflation of the TBL approach with the development of sound sustainability strategy, and sought new approaches that included consideration of strategic inputs and measurable value generation. Similarly, Isil and Hernke (2017) noted that as the TBL framework operates predominantly as a reporting tool, there is a tendency for organizations to cherry-pick "what" sustainability outcomes to report and "when" to report them; this can reduce sustainability strategy development into mere window dressing to enhance legitimacy as a response to government and/or public pressure. Getz (2017) amplified this point, noting that the periodic nature of events means that they necessarily evolve in ways that can "make them less green or sustainable over time, whatever the reporting criteria" (p. 577) that happen to be considered important at a given point in time.

The criticisms of the TBL approach to sustainability management and reporting (i.e., its overemphasis on sustainability outcomes and limited capacity to explore its strategic management) are also evident in the event literature. For example, the economic sustainability of events has commonly been addressed in terms of outcomes such as investment growth (Luonila \& Johansson, 2015; Ziakas \& Boukas, 2016), stakeholder value creation (Kwiatkowski, 2016; Maguire \& Hanrahan, 2017; Testa \& Metter, 2017), repeat visitation (Wong et al., 2015), and consumer behavior (Ma et al., 2011). Social sustainability has commonly been addressed in terms of outcomes such as education and awareness (Harris, 2014; Jiang \& Schmader, 2014; Lawton, 2009), inclusive practices (Laing \& Mair, 2015; Misener \& Mason, 2006), connectedness to location (Ma et al., 2011), building social capital (Davies, 2015; Jepson \& Stadler, 2017; Lawton \& Weaver, 2015), and health and well-being (Gibson \& Connell, 2015; Reid \& Ritchie, 2011; Schulenkorf \& Schlenker, 2017). Lastly, environmental sustainability has commonly been addressed in terms of outcomes such as ecological impacts (Andersson \& Lundberg, 2013; Collins \& Cooper, 2017; Collins \& Flynn, 2015), influencing attendee behavior (Hitchings et al., 2018), and biodiversity protection (Hvenegaard, 2011). Recognition of the limitations of the TBL framework, along with the need to advance our knowledge of effective sustainability management, have led to calls to examine the antecedent factors critical to the strategic management of economic, social, and environmental sustainability in the event sector (see Colombo, 2017; Larson et al., 2015; Ma et al., 2011). As such, the broad research opportunity addressed by this article is to explore which antecedent factors are associated with best-practice sustainability management in the event sector.

\section{Literature Review}

Despite its overwhelming emphasis on studying the sustainability outcomes of events, the event literature does provide some guidance as to the antecedent factors that scholars consider important to effective event management. These antecedent factors are generally categorized into four categories: (a) the event's physical location, (b) the event's reputation, (c) the event attendees' involvement, and (d) the event's infrastructure.

\section{Physical Location}

In terms of physical location, researchers have identified the importance of factors such as the touring route, cultural heritage, resident perceptions, festivalscape, and natural scenery (extending to local climate and weather conditions, etc.) as antecedents for effective event management (Gration et al., 2011; Luonila \& Johansson, 2015; Ziakas $\&$ Boukas, 2016). The research into the roles that physical location factors can play in event management has largely played out in terms of outcomes such as the creation of eventful cities and tourism trails, the leveraging of place-of-origin/country-oforigin advantages, destination marketing, and repositioning, etc. (see Antchak \& Pernecky, 2017; Getz $\&$ Page, 2016). As Kaplanidou et al. (2012) pointed out, physical location factors are complex and multidimensional in nature and have preeminently 
been considered in the narrow context of destination management; there are now calls to expand research and explore the utility of physical location factors in other tourism contexts-particularly as predictors of event sustainability (see Getz \& Page, 2016).

\section{Event Reputation}

In terms of event reputation, researchers identified the importance of stakeholder management, event legitimacy, relationship building, and the ability to generate in-kind support as antecedents for effective event management (see Larson et al., 2015; Musgrave \& Woodward, 2016; Schulenkorf $\&$ Schlenker, 2017). Given the episodic nature of events (both in terms of the event itself, and potentially the organizational infrastructure that underpins it), extant event management research has tended to deal with event reputation as an outcome requiring maintenance and/or reinforcement (particularly in terms of crisis management and managing the "down time" between scheduled events) (French \& Wickham, 2018). However, Lampel et al. (2013) noted that the complexity of the reputation management process requires the reputation construct to be researched as both an outcome to be strategically managed (e.g., in terms of stakeholder engagement and image management) and an input that can be used in the strategic generation of goodwill (e.g., in-kind support, preferred supplier status, etc.) that in turn can support improved event sustainability performance.

\section{Attendee Involvement}

In terms of the event attendees' involvement, researchers have identified the importance of attendee satisfaction, attendee motivation, and volunteer labor as antecedents for effective event management (see Michelini et al., 2017; Pernecky, 2015; Simons, 2017; Wong et al., 2015). As per the limitations of the TBL approach discussed earlier, these inputs have been predominantly studied in terms of their link to desired economic outcomes (e.g., repeat visitation intentions, positive wordof-mouth referrals, access to free labor, etc.) and the minimization of environmental harm-both during and postevent (i.e., positively influencing attendees' proenvironmental behavior). Similar to the reputation issue noted above, Ahmad et al. (2016) argued that to advance our understanding of sustainability in the event sector, research into the strategic roles that attendee behavior and attendee attitude can have as inputs to the event management process is needed (e.g., the range of attendee roles that exist - event ambassadors, quasi-tour guides, volunteer labor, etc.- - and how these roles can be coordinated as a network).

\section{Event Infrastructure}

In terms of event infrastructure, researchers have confirmed the importance that inputs inter alia management and marketing skill sets, leadership capabilities, supply chain management, and technological capabilities have for effective event management (see Davies, 2015; Ensor et al., 2011; Merrilees \& Marles, 2011). The shortcomings of the TBL approach in this regard have been highlighted by Werner et al. (2017), who noted that although event infrastructure elements are well-defined in the literature, there remains a persistent lack of knowledge regarding the network connectivity that exists between them, especially with regards to strategic event planning and implementation processes. In sum, there is growing agreement in the event management literature that the most successful events operate as formal organizations, and therefore must develop managerial competence and strategic ability in order study and sustain their economic, social, and environmental performance (French \& Wickham, 2018; Moise, 2015; Nordvall, 2016; Pino et al., 2019). This agreement has led to recent calls to explore the antecedents of best-practice sustainability management in the event sector, and a recognition of the role that strategic management theories [and, the Resource-based View of the Firm (RBV) in particular] might play in this regard (Camison \& Forés, 2015; Evans, 2016; Mair \& Laing, 2012). Musgrave and Woodward (2016) set an agenda to study event sustainability management in terms of strategic management theory, and this article seeks to answer their call to move beyond the conceptual to the empirical by adopting the RBV as a lens to explore which antecedent factors are associated with best-practice strategic sustainability management in the event sector. 


\section{The Resource-Based View of the Firm}

Over the past two decades, the RBV of the firm has become one of the most widely adopted theoretical perspectives in the strategic management literature (Barney, 2014; Newbert, 2007). At its core, the RBV seeks to provide insight into the sources underpinning an organization's competitive advantage in a given industry setting (Barney, 1991, 2014; Wernerfelt, 1984). The RBV of the firm is commonly used in the strategic management literature as a framework to infer the mix of resources and capabilities that underpin an organization's performance (see Leonidou et al., 2013; Takata, 2016). Resources refer to any tangible or intangible asset the firm owns or controls (and is able to draw upon) in its operations (Amit \& Schoemaker, 1993). Tangible assets are those resources that can be easily quantified and valued and are typically considered to be either financial (e.g., monetary or tradable commodities; see Barney, 1991) or physical in nature (e.g., plant and equipment; see Galbreath \& Galvin, 2004). Intangible assets are those resources that cannot be readily observed or measured (e.g., employee skills, abilities, and knowledge; see Ployhart \& Moliterno, 2011) and are most often considered the source of sustainable competitive advantage due to the difficulty for competing firms to acquire or imitate them (Cater \& Cater, 2009). In order to operationalize the RBV, researchers have aggregated the myriad of resources evident in empirical literature into broad categories to increase its usefulness as a lens for strategic management research (Barney, 2001). These broad resource categories are identified as: financial capital (e.g., liquid assets, equity, tradable commodities, etc.; see Barney, 1991, 2001), organizational capital (e.g., plant and equipment, organizational structure, organizational culture, planning processes, etc.; see Chen et al., 2005; Kristandl \& Bontis, 2007), reputational capital (e.g., brand equity, labor and consumer market image, etc.; see Saeed \& Arshad, 2012), and human capital (e.g., knowledge, ideas, skills, etc.; see Wright \& McMahan, 2011).

A capability, on the other hand, refers to the combination of two or more resources (i.e., often referred to as "bundles of resources") to engage in operational and/or strategic activities (Bryson et al.,
2007). Capabilities are often thought to be of greater value than individual resource assets, as they are often far more difficult to imitate due to their inherent complexity and ambiguity (Helfat \& Peteraf, 2003; Newbert, 2008). Although most capabilities are considered to be operational in nature (i.e., they underpin functional aspects of an organization's activities), RBV research has recently extended the concept to recognize the role of "dynamic capabilities" in the generation of a sustainable competitive advantage (i.e., the capability of some firms to nimbly integrate, build, and/or reconfigure their resources in response to opportunities and threats that emerge in rapidly changeable competitive environments; see Ambrosini \& Bowman, 2009). The use of the RBV as a framework to conceptualize and empirically study strategic sustainability management has become increasingly apparent in recent sustainability literature (see Amui et al., 2017), but has not yet been applied to sustainability management in the event management context (Camison \& Forés, 2015; Evans, 2016). Given the research opportunities identified above, the specific research question to be addressed in this article is: What resources and capabilities are associated with best-practice strategic sustainability management in the event sector?

\section{Methodology}

In order to address this research question, this study undertook a content analysis of the official websites of international music events that attained sustainability accreditation by The Greener Festival Awards organization for their 2017 event (see A Greener Festival, 2018a). The Greener Festival organization is a US-based nonprofit entity established in 2006 and has a stated mission to raise awareness and improve performance of music events in the realms of their economic, social, and environmental sustainability (albeit with an emphasis on environmental impacts). Since the inception of its awards program in 2007, the Greener Festival Award organization has assessed more than 400 music events worldwide (NB: events undergo a preevent audit, site visit, and postevent assessment of their sustainability performance; see A Greener Festival, 2018b). In order to qualify for inclusion in this study, the international music event had to have 
been awarded either an "outstanding" or "highly commended" accreditation from the Greener Festival Awards organization (i.e., to provide data representative of award-winning sustainability performance), and have an active website containing data relating specifically to their 2017 event (Table 1). In total, the content from the websites of three "outstanding" and seven "highly commended" award-winning music events were gathered for scrutiny; the text from each of the website's individual pages was captured (NB: the site-map function was used to ensure all website content was captured) and was subject to a rigorous three-stage content analysis process that followed the protocols recommended by Finn et al. (2000) and Neuman (2003).

In the first stage of the content analysis, the aims and objectives of the research were identified, and the first-round data coding rules were developed. Using the three major areas of sustainability evident in the literature as a guide (i.e., economic, social, and environmental), the data were initially organized by the sustainability criteria established in the Global Reporting Initiative's (GRI's) Sustainability Reporting Guidelines (2015) and accompanying Event Sector Supplement (Global Reporting Initiative, 2012), with the number of criteria totaling 21 (see Table 2). The GRI reporting guidelines provide an extensive framework for the best-practice reporting of economic, social, and environmental sustainability performance, and has emerged to be the most widely used framework world-wide since its inception in 2000 (Hindley \& Buys, 2012; Toppinen \& Korhonen-Kuri, 2013).
In the second stage of the content analysis, all the data from the event's websites were converted into MS Word ${ }^{\circledR}$ document format and entered into a codified NVIVO (version 12) database according to the coding rules set in Table 2. At regular intervals, intercoder reliability checks were undertaken to ensure that the data were coded consistently with the coding rules established in the previous stage. The intercoder reliability checking process for this research was based on the two-stage process recommended by Compton et al. (2012). Firstly, the researchers pretested the coding rules for the data gathered in $20 \%$ of the website content. Secondly, the researchers developed an agreement as to how ambiguous data were to be handled (i.e., an agreement as to how to handle instances where data could be coded in to more than one node). In the third stage of the content analysis, coded data were further interrogated as per the tenets of the RBV discussed in the literature review (see Table 3 for the RBV-related coding rules) to detect the array of tangible and intangible resources evident in the events' account of their sustainability activities and/or outcomes. In order to infer a plausible set of capabilities in this regard, additional coding of the data was undertaken to detect how the resources were used in conjunction to achieve the GRI sustainability criteria evident after the second stage coding process.

As per the previous stage, intercoder reliability measures were again adopted; the authors coded the data in tandem to ensure consensus regarding the relationships detected was maintained throughout. The creation of the codified database, the interpretation of the data during the second and third rounds

Table 1

Sample of Award-Winning Events in 2017

\begin{tabular}{lll}
\hline Event Name & \multicolumn{1}{c}{ Event Type } & \multicolumn{1}{c}{ Location } \\
\hline Cambridge Folk Festival & Folk Music & United Kingdom \\
DGTL Festival & Electronic Music & Netherlands \\
Greenbelt Festival & Popular Music & United Kingdom \\
Green Gathering $^{\text {a }}$ & Folk Music & United Kingdom \\
HebCelt Festival $_{\text {Ilosaarirock Festival }}$ & Folk Music & United Kingdom \\
OYA Festival & Popular Music & Finland \\
Paradise City & Popular Music & Norway \\
Roskilde Festival & Electronic Music & Belgium \\
We Love Green $^{\text {a }}$ & Popular Music & Denmark \\
\hline
\end{tabular}

Note. aEvents awarded for "outstanding" sustainability performance. 
Table 2

First-Round Coding Variables (GRI Guidelines)

\begin{tabular}{|c|c|}
\hline GRI Node & Coding Rules \\
\hline Economic performance & $\begin{array}{l}\text { This node captures any data relating to direct economic indicators reported by the } \\
\text { event. }\end{array}$ \\
\hline Market performance & $\begin{array}{l}\text { This node captures any data relating to market share and/or other marketing indica- } \\
\text { tors reported by the event. }\end{array}$ \\
\hline Indirect economic impacts & $\begin{array}{l}\text { This node captures any data relating to the event's impact on the local, regional, or } \\
\text { national economy. }\end{array}$ \\
\hline Procurement practices & $\begin{array}{l}\text { This node captures any data relating to the event organization's interactions with } \\
\text { supply chain organizations. }\end{array}$ \\
\hline Society & $\begin{array}{l}\text { This node captures any data relating to the event's impact on social issues relevant } \\
\text { to the location, region or nation. }\end{array}$ \\
\hline Labor practices & $\begin{array}{l}\text { This node captures any data relating to the event's human resource management } \\
\text { practices. }\end{array}$ \\
\hline Product responsibility & $\begin{array}{l}\text { This node captures any data relating to specific social responsibility elements of the } \\
\text { products and services offered to visitors to the event. }\end{array}$ \\
\hline Human rights & $\begin{array}{l}\text { This node captures any data relating to the event's activities and policies relating to } \\
\text { human rights issues. }\end{array}$ \\
\hline Materials & $\begin{array}{l}\text { This node captures any data relating to the goods and services purchased and/or } \\
\text { leased by the event. }\end{array}$ \\
\hline Energy & This node captures any data relating to the event's consumption of energy. \\
\hline Water & $\begin{array}{l}\text { This node captures any data relating to the event's consumption and/or conservation } \\
\text { of water. }\end{array}$ \\
\hline Biodiversity & $\begin{array}{l}\text { This node captures any data relating to the event's impact on and/or conservation of } \\
\text { flora and fauna. }\end{array}$ \\
\hline Emissions & $\begin{array}{l}\text { This node captures any data relating to the event's impact on and/or conservation of } \\
\text { the atmosphere. }\end{array}$ \\
\hline Effluents and waste & $\begin{array}{l}\text { This node captures any data relating to the event's management of effluent and } \\
\text { waste into landfill and/or waterways. }\end{array}$ \\
\hline Products and services & $\begin{array}{l}\text { This node captures any data relating to the event's range of products and services } \\
\text { offered to visitors to the event. }\end{array}$ \\
\hline Certification & $\begin{array}{l}\text { This node captures any data relating to external accreditation of the event's systems } \\
\text { and processes. }\end{array}$ \\
\hline Compliance & $\begin{array}{l}\text { This node captures any data relating to the event's compliance with relevant laws } \\
\text { and regulations. }\end{array}$ \\
\hline Transport & $\begin{array}{l}\text { This node captures any data relating to any transportation issues linked to the event } \\
\text { and/or visitors to the event. }\end{array}$ \\
\hline Supplier environmental assessment & $\begin{array}{l}\text { This node captures any data relating to the event's assessment of supply chain mem- } \\
\text { bers' environmental performance and impact. }\end{array}$ \\
\hline Environmental grievance mechanisms & $\begin{array}{l}\text { This node captures any data relating to the event's environmental grievance man- } \\
\text { agement processes. }\end{array}$ \\
\hline Overall environmental impact & $\begin{array}{l}\text { This node captures any data relating to the sum of the event's impact on the natural } \\
\text { environment. }\end{array}$ \\
\hline
\end{tabular}

Note. Sourced from Global Reporting Initiative (2012, 2015).

Table 3

Second-Round Coding Variables (RBV)

\begin{tabular}{ll}
\hline RBV Node & Coding Rules \\
\hline $\begin{array}{l}\text { Financial capital } \\
\text { Organizational capital }\end{array}$ & $\begin{array}{c}\text { This node captures any data relating to the liquid assets owned or under the control of the event. } \\
\text { This node captures any data relating to the structural resources owned or under the control of the } \\
\text { event. } \\
\text { Reputational capital }\end{array}$ \\
$\begin{array}{c}\text { This node captures any data relating to relationship-based resources owned or under the control of } \\
\text { the event. } \\
\text { This node captures any data relating to the knowledge and skill-based resources owned or under the } \\
\text { control of the event. } \\
\text { This node captures any relationships between tangible and/or intangible resources that underpinned } \\
\text { a sustainability activity or outcome. }\end{array}$ \\
\hline
\end{tabular}


of coding, and the verification of the conclusions, were all facilitated by the use of the NVIVO software package. Where it was appropriate, data were allocated to more than one "node" for analysis; using the NVIVO software, the contents of each of the initial index nodes were reviewed to identify common themes that arose in the data pertaining to sustainability priorities. In order to facilitate the theory building process, research memos about the data, their categories, and the relationships between them were created in NVIVO's memo facility. These memos were retained, and after the data coding processes were complete, reports were generated by the software for consideration and analysis. From these memos, the events' sustainability capabilities were inferred; the results of the method described above will be discussed in the results section that follows.

\section{Results}

The second stage coding data indicated that 17 of the 21 GRI Sustainability/Event Sector Supplement reporting guidelines were detected in the websites of the award-winning events. The frequency data (see Table 4) indicates that in terms of the GRI's economic sustainability issues, all of the events' websites included sustainability data related to Market Performance and Economic Performance. A majority of event websites $(n=8)$ included sustainability data relating to their Procurement Practices, while a minority of events $(n=2)$ reported on Indirect Economic Impacts as they related to the local economy. In total, $33.6 \%$ of the total coded data related to the GRI's economic sustainability issues. In terms of the GRI's social sustainability issues, the majority of event websites ( $n=9,9$, and 8 , respectively) included sustainability data relating to Society, Labor Practices, and Product Responsibility (and in total, represented $28.3 \%$ of the coded data); notably, there were no data detected that related to Human Rights sustainability issues on any of the sample events' websites. In terms of environmental issues, all of the events' websites included sustainability data related to Overall Environmental Impact and

Table 4

Frequency Data

\begin{tabular}{lcc}
\hline GRI Node & $\begin{array}{c}\text { No. of Events } \\
\text { Reporting: X/10 }\end{array}$ & $\begin{array}{c}\text { Coding References } \\
\text { Frequency (\% of total) }\end{array}$ \\
\hline Economic sustainability & 10 & $62(13.5 \%)$ \\
$\quad$ Market performance & 10 & $27(5.9 \%)$ \\
Economic performance & 8 & $42(9.4 \%)$ \\
Procurement practices & 2 & $22(4.8 \%)$ \\
Indirect economic impacts & & $\mathbf{1 5 4}(\mathbf{3 3 . 6 \% )})$ \\
Subtotal & & \\
Social sustainability & 9 & $45(9.8 \%)$ \\
Society & 9 & $37(8.1 \%)$ \\
Labor practices & 8 & $48(10.5 \%)$ \\
Product responsibility & 0 & $0(0 \%)$ \\
$\quad$ Human rights & & $\mathbf{1 3 0}(\mathbf{2 8 . 3 \% )})$ \\
Subtotal & 10 & \\
Environmental sustainability & 10 & $57(12.4 \%)$ \\
Overall environmental impact & 9 & $31(6.8 \%)$ \\
Products and services & 7 & $25(5.4 \%)$ \\
Effluents and waste & 7 & $17(3.7 \%)$ \\
Emissions & 6 & $10(2.2 \%)$ \\
Compliance & 5 & $15(3.3 \%)$ \\
Transport & 3 & $7(1.5 \%)$ \\
Water & 3 & $7(1.5 \%)$ \\
Supplier environmental assessment & 1 & $4(0.9 \%)$ \\
Energy & 0 & $2(0.4 \%)$ \\
Certification & 0 & $0(0 \%)$ \\
Biodiversity & 0 & $0(0 \%)$ \\
Environmental grievance mechanisms & & $0(0 \%)$ \\
Materials & $\mathbf{1 7 5}(\mathbf{3 8 . 1 \% )}$ \\
Subtotal & & \\
\hline & &
\end{tabular}


their range of Products and Services (19.2\% of the total coded data); a majority of event websites included sustainability data relating to Effluents and Waste $(n=9)$, Emissions $(n=7)$, Compliance $(n=7)$, and Transport $(n=6)$. Data relating to Water sustainability was detected in half of the event's websites (but accounted for only 1.5\% of the total coded data). Notably, only a minority of event websites included sustainability data relating to Supplier Environmental Assessment $(n=3)$, Energy $(n=3)$, and Certification $(n=1)$, and there were no data detected relating to Biodiversity, Environmental Grievance Mechanisms, or Materials. In total, $38.1 \%$ of the coded data related to the GRI's environmental sustainability issues.

The third stage of the content analysis process described above sought to detect the resources and capabilities associated with the GRI reporting guidelines in terms of the various forms of capital owned or under the control of the sample events. The resources and capabilities detected as underpinning CSR activities are identified and described below in terms of the RBV resource capital typologies described in the Methodology section.

\section{Financial Capital}

In terms of financial capital, three specific resources were identified in the data: donations from the events' attendees, sponsorships from the events' benefactors, and in-kind support by the events' volunteer workforce. In terms of donations from the events' attendees, the data indicated that monetary donations were used as a resource to secure the firm's ongoing economic viability:

Donations: Covers the financial or human resources that we allocate or provide to strengthen sustainability in our surrounding world based on the Foundations and Societies objective about supporting initiatives. (Rosklide Festival)

We affectionately call anyone who makes regular donations to Greenbelt one of our Angels. Greenbelt Angels provided incredible 27\% of our income. The festival simply couldn't survive without them. (The Greenbelt Festival)

Cambridge Folk Festival is extremely grateful to all our supporters whose contributions help enormously towards making the Cambridge Folk
Festival run as smoothly as ever. (Cambridge Live Festival)

In terms of sponsorships from the events' benefactors, the data similarly indicated that sponsorship funds were used a resource to secure the firm's ongoing economic viability:

The Festival has a range of opportunities .. . including title sponsorship, ancillary and stage sponsorships, campsite sponsorship, product supply and pouring rights, advertising partnerships and more. Cambridge Folk Festival is extremely grateful to all our sponsors and supporters whose contributions help enormously towards making the Cambridge Folk Festival run as smoothly as ever. (Cambridge Live Festival)

Becoming one of the festival's friends is also your own unique way of becoming a festival ambassador. 2018 friend's scheme offers fantastic benefits: Free festival t-shirt Personalized Friends pass access to our guest area on site; access to late night events of your choice. ... (Hebridean Celtic Festival)

Become a 1965 Club Member and help us deliver on our ambitions for the next 50 years (and beyond). To show our thanks, you can look forward to some unique benefits making your Cambridge Folk Festival experience even more enjoyable! And, for Folks who can make it, these benefits also apply to events across the city in our new winter music festival, City Roots and Beyond the Festival events at Cambridge Corn Exchange. (Cambridge Live Festival)

In terms of in-kind support, the data indicated that in-kind support from the volunteer workforce were used a resource to (a) secure the firm's ongoing economic viability, and (b) support the enactment of the event program:

Greenbelt is handmade, delivered with the support of hundreds of volunteers, you can visit our Get Involved pages for those roles. From time to time we also have opportunities to join the small, friendly staff team, working in London year-round to produce the annual festival of arts, faith and justice. (The Greenbelt Festival)

The Festival is proud to be committed to being a Greener Festival and we would like to thank all of the volunteers and workers who helped to keep the Festival site clean and tidy during the weekend. (Cambridge Live Festival) 
It is the first time the students, aged $18-22 \ldots$. They will help the set-up for the Stornoway-based event and will be involved in building the stages, assisting with the set-up of the sound systems as well as with stage management and technical support for the front-of-house and monitor engineers. (Hebridean Celtic Festival)

Volunteers make an invaluable contribution to making the festival happen. Volunteer work is, by nature, work carried out by free will, which means that no money is paid for it. Every volunteer gets free entrance to the festival area-and wherever else your tasks require. (Ilosaarirock Festival)

Analysis of the data provided support for the role of financial capital as a resource underpinning bestpractice economic sustainability management in the event sector. Their capacity to attract monetary and in-kind support demonstrates the events' capabilities to use their management and marketing skills (and supporting organizational structure) to attract financial capital from sustainability-conscious donors and sponsors, and to attract, motivate, and retain in-kind financial support from the volunteer labor market.

\section{Organizational Capital}

In terms of organizational capital, four specific resources were identified: permanent corporate infrastructure, the events' physical location, supply chain relationships, and management information systems (MIS). In terms of permanent corporate infrastructure, the data indicated that the events were able to maintain permanent management functions throughout the year to deal with the complex nature of their event operations. It was common among the events to report the presence of ongoing corporate entities such as Boards of Trustees, and full-time management and marketing positions inside the event organizations:

The Board of Trustees of the Green Gathering Charity is made up of volunteers committed to delivering on the Charity objectives. The Trustees are the only formal members of the charity but we invite anyone who supports our objectives and ethos to become a "Community Member." (The Green Gathering Festival)

The best way to stay connected with the Greenbelt community year-round is to get yourself on our e-mail list for news and updates. Were on all the usual social media platforms too. (The Greenbelt Festival)

The permanent corporate infrastructure resource enabled the events to maintain a range of professional management and marketing functions between their enacted events (e.g., human resource management, marketing, procurement, governance, and reporting, etc.):

Do you want to work at Cambridge Folk Festival? Do you want to be part of the team that delivers one of the best Festivals in the land? Do you have exceptional customer service skills and the ability to keep your head when all around you are losing theirs? If this sounds like you then read on. (Cambridge Live Festival)

All stewards wearing "STAFF" T-shirts will have been briefed on our facilities for people with disabilities. There are designated stewards for disabled customers, driving accessible minibuses and working at the disabled viewing areas. Please ask stewards for any help or advice you may need over the weekend. (Cambridge Live Festival)

You need to apply to be a volunteer. Please fill in our application form. The permanent crew of Ilosaarirock Festival aim at finding the right tasks for the volunteers during the spring and early summer. They will contact you either by phone or e-mail. All applicants will be informed about the selection by Tuesday, July 3. (Ilosaarirock Festival)

In terms of the "physical location" resource, the data indicated that the events were able to consistently secure premium locations and regular calendar timeslots to accommodate their multiday programs:

Cherry Hinton Hall campsite is a beautiful 36-acre park complete with a duck pond, sculptures, lovely trees, and a country house. The campsite is just a short walk from the main arena and all the Festival's facilities and has a wonderful atmosphere. (Cambridge Live Festival)

The camping fields at the Green Gathering is spacious. You'll be able to choose whether to camp close in to the entertainments, or a peaceful spot on the edge of the woods. (The Green Gathering Festival)

Like last year this restaurant will be located on a breathtaking spot on the castle peninsula, between 
the castle and the Orangery with a stunning view of the water and the main stage. (Paradise City Festival)

Ilosaarirock Festival hosts two camping sites located right next to the festival area. The larger of the sites, Ravileirintä, is an ideal choice for those about to party, while Niittyleirintä is the right one for festival guests looking for higher-end services and peaceful sleep. (Ilosaarirock Festival)

In terms of the supply chain relationships resource, each of the events reported establishing commercial partnerships with sustainabilityconscious vendors, and using these partnerships to offer a range of products and services relevant to the events' ethos (e.g., local/organic foodstuffs, camping accommodation, fair trade goods and services, environmentally friendly clothing, etc.):

When possible, we will only buy and rent eco-label products. In 2017 our goal was to buy eco-label products and materials exclusively in 10 product groups. (Roskilde Festival)

T-shirts, hoodies, and all other Ilosaarirock Festival merchandise on sale are made of ethically and ecologically produced cotton. The carbon footprint from producing these items has been brought down as much as possible. The decorations of the festival are made primarily of recycled materials. (Ilosaarirock Festival)

The print house that Ilosaarirock Festival works with, Punamusta, has received the Nordic ecolabel for its environmental actions. The paper used in the printed materials, on the other hand, has been awarded the PEFC certificate which proves that the paper comes from sustainably managed forests. (Ilosaarirock Festival)

The supply chain relationships resource was also used by the events to establish partnerships with a range of charitable institutions (either in the event's local community area, or in a special-interest sector) that were relevant to its ethos and desired impact, and provided additional bases for delivering valued experiences for the event attendees:

Welcoming the news, Cambridge Live's Director of Operations, Neil Jones said: "As an organization we place great importance on ensuring that everyone who accesses our venues and events has both an excellent and equal experience. We're pleased to be working with Attitude Is Everything and look forward to continue to welcome deaf and disabled visitors to our venues and events" (Cambridge Live Festival).

Each year a number of local and national charities and organizations are assisted by the Hebridean Celtic Festival Trust through fund raising opportunities. . . Macmillan Cancer Support Margaret-Ann Maciver receiving a cheque from Caroline Maclennan on behalf of the Hebridean Celtic Festival Trust for monies donated to Macmillan Cancer Support by festival goers over the last three years. We are proud to continue to support their worthwhile fundraising efforts. (Hebridean Celtic Festival)

Ilosaarirock Festival invests in ethical choices and the festival is a Fairtrade companion. In environmental work, Ilosaarirock Festival has partnered with UNESCO, for example. Ilosaarirock Festival has environment principles that help diminish environmental drain. (Ilosaarirock Festival)

In addition to this, the events took measures to incorporate the specialized knowledge and skills possessed by their supply chain partners into their organizational structure in order to offer products and services that were inclusive of marginalized groups in the music event context (i.e., people with disabilities):

We work hard to ensure that disabled people, and their friends, are welcomed and included at Greenbelt. One of the ways we do this is by designating the area closest to the entrance for disabled camping. (The Greenbelt Festival)

MUSIC Without Barriers is the message at the heart of leading access charity, Attitude is Everything, set up to transform deaf and disabled people's access to live music. And Cambridge Live is delighted to announce that both Cambridge Corn Exchange ... have been awarded Bronze for the level of access now achieved. (Cambridge Live Festival)

Deaf access: Access to support is available. Each year we aim to expand provision. In 2017 we had hearing loops in the Assisted Access Box Office, speakers [sic] forum and Soundscape Solar Stage. (The Green Gathering Festival)

In terms of the MIS resource, the events demonstrated capabilities to undertake sophisticated information gathering and boundary-spanning activities 
relating to their environmental impact (i.e., capturing data concerning the event's own environmental footprint as well as benchmark information from ecological agencies, government reports, etc.), and report the information to their stakeholders:

From the start in 2015, we decided to minimize the carbon footprint of the festival, and go full on for a green policy. Each year we accelerate our efforts, and in 2018 we want to take additional steps towards a more ecological festival with less waste, less emissions and more delicious \& sustainable food. (Paradise City Festival)

Electricity consumption is monitored and calculated very carefully during the festival. Before the festival, each contributor, including sound and lighting suppliers, partners, and vendors, need to provide exact calculations of how much their equipment consumes electricity. (Ilosaarirock Festival)

In 2017, all our generators were using bio fuel and their capacity was reduced from 800 to $420 \mathrm{kVA}$ since our first year. Furthermore, our camping area was $100 \%$ powered on solar energy for 2 years in a row and we use $95 \%$ of low consumption lighting on site. (Paradise City Festival)

DGTL has saved over 6.2 million liters of water by choosing Pure Waste as a supplier (DGTL Festival).

Analysis of the data indicated support for the role of organizational capital as a resource underpinning best-practice sustainability management in the event sector. In terms of the permanent corporate infrastructure, the sample events demonstrated the capability to maintain a range of permanent management and marketing functions throughout the year that were critical to their economic, social, and environmental performance (e.g., HRM recruitment, marketing activities, stakeholder engagement, maintenance of supply chain relationships, etc.). In terms of the events' location, the events reported the ability to use their permanent organizational infrastructure to plan the event logistics and secure the required leases for the event locations in an effective manner. In terms of supply chain relationships, the data indicated that the sample events had the capability to leverage their reputational capital to establish and maintain relationships with a range of commercial and social enterprises (which, in turn, served to increase the scope and impact of the events' social and environmental performance). In terms of MIS, the data indicated that the sample events were able to use knowledge management skills and organizational infrastructure to gather sophisticated environmental sustainability information and integrate that information into their operations (i.e., guiding environmental volunteer activities, selecting retailers, etc.).

\section{Reputational Capital}

In terms of reputational capital, two specific resources were identified: supply chain influence and attendee goodwill. The data indicated that the sample events were able to leverage their reputation and ethos in the event sector as a resource to influence (and in certain cases control through the use of contracted agreements) the sustainability policies and activities of their supply chain partners:

Caterers at this year's event, which will run from 19-21 July in Stornoway, have now been asked to serve soft drinks in paper cups and continue to use $100 \%$ biodegradable plates and cutlery (Hebridean Celtic Festival).

We Love Green and its partners help and advise caterers on this green transition, whereby caterers are required to serve an original and tasty vegetarian option on their menu. . . . We Love Green assist the chosen caterers in sourcing organic produce, ensuring 100\% product traceability. (We Love Green Festival)

We ask our food trucks to use only compostable silverware. And, if any, we collect the food surplus to be distributed to people in need. (Paradise City Festival)

In terms of the attendee goodwill resource, the data indicated that the event organizations were able to influence the environmental behavior of event attendees, and draw upon their labor in the achievement of their environmental management goals:

In the Utopia, there is no such thing as waste. Our festival goers, ourselves, and our partners take most of it with them home. What is left behind is viewed as resources. Therefore, we, our festival goers and partners ... reuse the resources in the existing form or recycled for new products. (Rosklide Festival) 
Festival organizers have introduced a number of measures relating to the sustainable use of resources, reducing emissions, and raising awareness of environmental matters among volunteers, suppliers, contractors, artists, and festival goers. (Hebridean Celtic Festival)

The festival audience can also participate in reducing the amount of waste. "Bin it where it belongs" is a good piece of advice that you can keep in mind throughout the festival weekend. (Ilosaarirock Festival)

Concretely, we trust we can influence change by leaving a positive legacy and hopefully inspiring our visitors to live more sustainably. We believe in a positive future where we don't draw up more resources than nature can regenerate. (Paradise City Festival)

All of the events sampled in this study reported a capability to leverage their reputation to influence their supply chain relationships to increase the impact and scope of their combined social and environmental sustainability activities. In addition to this, the events reported a capability to leverage their reputation to influence the behavior and environmental actions of their event attendees (and in particular, influence them to undertake de facto volunteer labor tasks). This capability was particularly effective in reducing the financial costs of running the event while simultaneously increasing its social impact and decreasing the events environmental impact.

\section{Human Capital}

In terms of human capital, two specific resources were identified: artists and performers, and knowledge of the skills possessed by the events' invited guests. In terms of the talent and skills of the events' artists and performers, all of the sample events reported the capability to leverage their reputational capital to attract a range of artists and performers relevant to the events' ethos and sufficiently marketable to their target market attendees:

This year Paradise City will be spread over three full days, with a mixture of the finest selectors and live acts bringing you the warmer side of electronic music. Some of them are renowned tastemakers and need no introductions, others are crammed with talent and demand to be explored by your curious ears. (Paradise City Festival)

Having gained a first-class Honors Degree in Scottish Music from the Royal Conservatoire, he has now completed his Master's in Music. He has twice been nominated for a BBC Radio 2 Young Folk Award, has picked up a Danny Kyle award at Celtic Connections and was a finalist in BBC Radio Scotland Young Traditional Musician of the Year in 2015 and 2016. (Hebridean Celtic Festival)

Every year, We Love Green invites wild and exciting artists who draw the music of our time. An eclectic program that crosses the bridges between indie and electro. A French scene does not lack lights (Christine \& The Queens, Camille) and a window on the new pop rock guard. But above all, a great desire for diversity in all forms of hip-hop: from the first festival of PNL to the coronation of Action Bronson, and incredible performances of the new jewels Anderson. Paak or Damso. (We Love Green Festival)

In addition to the musical experience offered, each of the sample events demonstrated the capability to leverage their reputational capital to attract a range of invited experts in their field to offer educational opportunities for the events' attendees (including the artists and performers):

The Hub Band Project is a series of workshops at The Hub youth music area, where, led by four fantastic tutors from the world of folk and roots music, you will collaborate with other young musicians, forming The Hub Band. This will culminate in a performance by The Hub Band on stage in the Club Tent on Sunday evening 5th August 2018. (Cambridge Live Festival)

The Campaigns Field is the center of politics in protest at the Gathering - bringing together activists and academics, and raising awareness around the diverse social and environmental justice issues. Every day is jam packed with discussions and workshops. (The Green Gathering Festival)

Not only do we coordinate cultural events, but with the help from our industry-insiders and artist collaborators, we also play an educational role. We hope that via music, we can spread economical, social, and solidarity values! (We Love Green Festival)

At DGTL Revolution we explore new ways of thinking, new forms of design, new cultural 
Table 5

Summary of the Resources Evident in the Sample Events' Website Information

\begin{tabular}{|c|c|}
\hline Resource Category & Resources \\
\hline \multirow[t]{3}{*}{ Financial capital } & Donations \\
\hline & Sponsorships \\
\hline & In-kind support \\
\hline \multirow[t]{4}{*}{ Organizational capital } & Permanent corporate infrastructure \\
\hline & Event location \\
\hline & Supply chain relationships \\
\hline & Management information systems \\
\hline \multirow[t]{2}{*}{ Reputational capital } & Community support for the event \\
\hline & Attendee goodwill \\
\hline \multirow[t]{2}{*}{ Human capital } & Artists and performers \\
\hline & Experts and educators \\
\hline
\end{tabular}

adaptations, and present these concepts in engaging, thought provoking ways. We aim to facilitate change through interaction. Not by dreaming of possible solutions, but by actually presenting them. (DGTL Festival)

All of the events sampled in this study reported their capability to leverage their reputation to attract and provide a range of specialized knowledge, skills, and networking opportunities to the events' attendees. This capability served to demonstrate the events' impact and value to the immediate target market for the event (i.e., the event's attendees) and generate positive word-of-mouth and community support (i.e., reputational capital) that it can leveraged in future operations.

\section{Discussion}

Tables 5 and 6 provide a summary of the resources and capabilities associated with strategic sustainability management in the sample of award-winning music events. Table 5 presents the resources evident in the data as grouped by the broad RBV categories cited in the extant literature (see Helfat $\&$ Peteraf, 2003; Winter, 2003). Table 6 presents the plausible capabilities of the award-winning events as they relate to the GRI's economic, social, and environmental sustainability reporting categories.

The findings of this study tend to affirm the importance of the critical inputs identified in the event management literature (i.e., the event's physical location, reputation, attendees' involvement, and infrastructure). However, the findings also provide additional insights into the role that each play in best-practice sustainability management in the event sector. In terms of the event's physical location, the findings of this research affirm the critical importance of an appropriate "place" for enactment of the award-winning events. Adding to knowledge, findings provide additional detail about the importance of the events' organizational infrastructure and ability to leverage its reputational capital to secure the critical physical locations required yearon-year. In terms of the events' reputational capital, the findings of this research confirm the importance of being able to establish and leverage a positively differentiated position in a crowded events marketplace to attract attendees and vendors. Adding

Table 6

Summary of the Capabilities Evident in the Sample Events' Website Information

\begin{tabular}{ll}
\hline GRI Category & \multicolumn{1}{c}{ The Events Demonstrated the Capability to: } \\
\hline Economic & Attract financial capital from sustainability-conscious citizens and organizations \\
& Attract, motivate, and retain in-kind financial capital support from the volunteer labor market \\
& Attract a range of relevant artists and performers to the event \\
& Maintain permanent management functions throughout the year \\
& Secure premium locations to accommodate their event programs \\
& Capture and report data relating to the economic benefits associated with the events' program \\
Social & Attract a range of relevant experts and influential educators to the event \\
& Engage in mutually beneficial supply chain relationships with social enterprises \\
& Offer products and services that are inclusive of marginalized groups \\
Environmental & Capture and report data relating to the social benefits associated with the events' program \\
& Influence event attendees' environmental behavior \\
& Engage in mutually beneficial supply chain relationships with ecological organizations \\
& Influence supply chain partners' environmental activities \\
& Capture and report data relating to the environmental benefits associated with the events' program \\
\hline
\end{tabular}


to this knowledge, findings provide additional detail regarding the need to carefully manage the self-reinforcing and iterative nature of reputational capital in the event context. For example, recognition that the extent to which the award-winning events were effective in attracting funding, in-kind support, and relevant supply chain partnerships, was dependent on the extent to which it was able to attract relevant artists and performers, invited guests, and sufficient numbers of event attendees (with the reverse also appearing to be the case). The findings also suggest that the award-winning events' reputational capital resources operated as both an outcome of the events' sustainability management practices (i.e., in terms of underpinning an improved reputation and a positively differentiated market position) as well as an input into them (i.e., in terms of underpinning influence and power in supply chain relationships and influence over event attendees' behaviors and actions). The findings of this study also affirm previous research concerning attendee involvement and their role in minimizing the environmental harm caused by the event and demonstrates how event attendees' can be used as a resource to act as de facto volunteer labor for the event organization. In terms of event infrastructure, the findings of this research similarly affirm the role of effective management, leadership skills, and supply chain relationship management in the enactment of the event. The findings also demonstrate how the permanence of the organizational infrastructure is important in the efficient deployment of the event's financial, reputational, and human capital resources across the calendar year, and underpins its ability to establish and maintain mutually beneficial supply chain relationships that amplify the scope and impact of its sustainability performance.

In addition to the affirmation of the inputs evident in the extant event literature, this study offers two additional insights into the resources and capabilities relating to best-practice sustainability management in the event context. Firstly, the results demonstrated that all of the sampled awardwinning events set goals relating to all three of the GRI's major sustainability reporting criteria, despite the emphasis given to environmental factors in the event literature and by accrediting bodies in the event industry. This suggests that those engaged in best-practice sustainability management in the event sector are cognizant of the interrelationship between the three sustainability measures and manages the various factors as part of a coherent whole. Therefore, the implications for event managers is to note that the effective management of sustainability on any one given factor is necessarily dependent on the other two factors also being equally well managed. In other words, it is evident that for an event to optimize its environmental sustainability outcomes, it must also seek to simultaneously optimize the management of its economic and social sustainability (and so on, iteratively). Secondly, while the results demonstrated that all three measures of sustainability were evident in the events' goals, measurements, and outcomes, data clustered around a number of apparently critical GRI sustainability criteria. As a cohort, the awardwinning events appeared to focus their sustainability management and reporting on three economic factors (i.e., market performance, economic performance, and procurement practices), three social factors (i.e., society, labor practices, and product responsibility), and seven environmental factors in particular (i.e., overall environmental impact, products and services, effluents and waste, emissions, compliance, transport, and water). These results suggest that best-practice sustainability management in the music event context requires a focus on particular set of sustainability criteria that reflects the needs and expectations of their salient stakeholder groups.

\section{Conclusion}

This article sought to address the question: What resources and capabilities are associated with bestpractice strategic sustainability management in the event sector? In doing so, three financial, four organizational, two reputational, and two human capital resources were identified in the website content of the sample award-winning events. In addition to this, the resources identified were used in combination to underpin 14 best-practice sustainability management capabilities. These results provide support for the RBV's suitability as lens for the study of best-practice strategic sustainability management in the event sector. In particular, the RBV framework adopted in this research was demonstrably useful in 
detecting the critical resources in the events' official communications and allowed for the inference of capabilities linked to their best-practice strategic sustainability practices in their industry. Therefore, used to its fullest extent, the RBV could serve as a tool for the longitudinal exploration of dynamic capabilities associated with best-practice strategic sustainability management that underpin a sustained competitive advantage in the event sector. However, the findings and implications of this research need to be assessed in relation to the limitations of the chosen method and data sample. Firstly, the content analysis method adopted in this study is necessarily limited to the available text and graphics available on the sample events' websites at a given point in time, which may not have included information relating to the full array of the events' sustainability management practices. In addition to this, the crosssectional data sample did not present sustainability management practices as they may have related to critical incidents (e.g., there was no postcrisis sustainability management evident in this data sample). Secondly, the events sampled in this study were all operating in the live music context only; while the live music event context is considered one of the most important in terms of market penetration, growth, and impact on the environment, the findings of this study may not be readily generalizable to other event types (e.g., mega-events, conferences, sporting, etc.) and in other industry settings (e.g., food and agriculture, art and culture, etc.). Lastly, the accrediting body (and all of the events achieving accreditation studied for this research) were based in predominantly Western social and economic settings, and the findings presented here do not necessarily reflect what best-practice sustainability management might comprise in non-Western social and economic settings.

Given these limitations, is a recommended that additional research be undertaken in four key areas. Firstly, additional research exploring the extent to which the findings presented in this study are valid in events operating in different industry sectors (and social and economic settings) to gauge the impact these might have on the sustainability management process. There is also an opportunity to capture a wider array of sustainability data than that published in event websites; the capture of information from external secondary data sources (e.g., newspaper accounts, trade magazine reports, government reports, etc.) would provide a basis for triangulation and verification of the link between an event's sustainability management practices and their sustainability performance. Primary data gathered from a range of key informants (e.g., senior executives, CEOs, etc.) would also be useful for verifying and expanding on the findings presented in this study. Secondly, given the apparently critical importance of reputational capital in the sustainability management process, there is an opportunity to explore its role as a strategic resource in greater depth - particularly in terms of its composition and the manner in which its constituent elements interact to deliver above-average sustainability performance over time. Thirdly, there is an opportunity to undertake research into events that have experienced a range of different critical incidents (e.g., crisis management, reputational damage, death or injury to an event attendee, etc.) that can provide insight into how an event deploys its resources and/or demonstrates a new range of sustainability management capabilities in response to them. Lastly, and in order to generate a generalizable set of findings concerning resources and capabilities and their relationship to best-practice sustainability management in the event industry, research based on quantitative research designs appear warranted. Quantitative or mixed-method research could be used to establish the nature of any causal relationships that exist between an event's resources and capabilities, and its selection of sustainability management processes.

\section{References}

A Greener Festival. (2018a). Previous winners. https://www. agreenerfestival.com/agf-awards/previous-winners

A Greener Festival. (2018b). AGF award. https://www. agreenerfestival.com/agf-awards/a-greener-festivalaward/

Ahmad, N. L., Yunus, N. A. M., Rashid, W. E. W., Zamzuri, N. H., Mahmood, N. H. N., \& Shamsuddin, S. (2016). Theorizing event attendees' behavior to increase the demand for sustainable events. International Business Management, 10(17), 3853-3859. https://medwelljournals.com/abstract/?doi=ibm.2016.3853.3859

Ambrosini, V., \& Bowman, C. (2009). What are dynamic capabilities and are they a useful construct in strategic management? International Journal of Management Reviews, 11(1), 29-49. https://doi.org/10.1111/j.14682370.2008.00251.x 
Amit, R., \& Schoemaker, P. J. (1993). Strategic assets and organizational rent. Strategic Management Journal, 14(1), 33-46. http://links.jstor.org/sici?sici=0143-2095$\% 28199301 \% 2914 \% 3$ A $1 \% 3$ C33\%3ASAAOR\%3E2.0. CO $\% 3 \mathrm{~B} 2-8$

Amui, L. B. L., Jabbour, C. J. C., de Sousa Jabbour, A. B. L. S., \& Kannan, D. (2017). Sustainability as a dynamic organizational capability: A systematic review and a future agenda towards sustainable transition. Journal of Cleaner Production, 142, 308-322. https://doi.org/10. 1016/j.jclepro.2016.07.103

Andersson, T. D., \& Lundberg, E. (2013). Commensurability and sustainability: Triple impact assessments of a tourism event. Tourism Management, 37, 99-109. https://doi. org/10.1016/j.tourman.2012.12.015

Antchak, V., \& Pernecky, T. (2017). Major events programming in a city: Comparing three approaches to portfolio design. Event Management, 21, 545-561. https://doi.org $/ 10.3727 / 152599517 X 15053272359013$

Barney, J. B. (1991). Firm resources and sustained competitive advantage. Journal of Management, 17(1), 99-120. https://doi.org/10.1177/014920639101700108

Barney, J. B. (2001). Is the resource-based "view" a useful perspective for strategic management research? Yes. Academy of Management Review, 26(1), 41-56. https:// www.jstor.org/stable/259393

Barney, J. B. (2014). Gaining and sustaining competitive advantage. Pearson Higher Education.

Bryson, J. M., Ackermann, F., \& Eden, C. (2007). Putting the Resource-based view of strategy and distinctive competencies to work in public organizations. Public Administration Review, 67(4), 702-717. https://doi.org/ 10.1111/j.1540-6210.2007.00754.x

Camison, C., \& Forés, B. (2015). Is tourism form competitiveness driven by different internal or external specific factors? New empirical evidence from Spain. Tourism Management, 48, 477-499. https://doi.org/10.1016/j. tourman.2015.01.001

Cater, T., \& Cater, B. (2009). (In)tangible resources as antecedents of a company's competitive advantage and performance. Journal of East European Management Studies, 14(2), 186-209. http://www.jstor.org/stable/ 23281130

Chen, M.-C., Cheng, S.-J., \& Hwang, Y. (2005). An empirical investigation of the relationship between intellectual capital and firms' market value and financial performance. Journal of Intellectual Capital, 6(2), 159-176. https://doi.org/10.1108/14691930510592771

Collins, A., \& Cooper, C. (2017). Measuring and managing the environmental impact of festivals: The contribution of the Ecological Footprint. Journal of Sustainable Tourism, 25(1), 148-162. https://doi.org/10.1080/09669582. 2016.1189922

Collins, A., \& Flynn, A. (2015). The ecological footprint: New developments in policy and practice. Edward Elgar Publishing.

Colombo, A. (2017). Music festivals and eventfulness: Examining eventful cities by event genres and policy agendas. Event Management, 21, 563-573. https://doi. org/10.3727/152599517X15053272359022

Compton, D., Love, T., \& Sell, J. (2012). Developing and assessing inter-coder reliability in studies of group interaction. Sociological Methodology, 42(1), 348-364. https://doi.org/10.1177/0081175012444860

Davies, A. (2015). Life after a festival: Local leadership and the lasting legacy of festivals. Event Management, 19(4), 433-444. https://doi.org/10.3727/152599515X14465748 512524

Ensor, J., Robertson, M., \& Ali-Knight, J. (2011). Eliciting the dynamics of leading a sustainable event: Key informant responses. Event Management, 15, 315-327. https://doi.org/10.3727/152599511X13175676722483

Evans, N. G. (2016). Sustainable competitive advantage in tourism organizations: A strategic model applying service dominant logic and tourism's defining characteristics. Tourism Management Perspectives, 18, 14-25. https://doi.org/10.1016/j.tmp.2015.12.015

Finn, M., Elliott-White, M., \& Walton, M. (2000). Tourism and leisure research methods: Data Collection, analysis and interpretation. Pearson Education.

French, L., \& Wickham, M. D. (2018). Exploring the reputation management process for events: The case of Targa Tasmania. Event Management, 22(2), 213-235. https:// doi.org/10.3727/152599518X15173355843361

Galbreath, J., \& Galvin, P. (2004). Which resources matter? A fine-grained test of the resource-based view of the firm. Academy of Management Proceedings, L1-L6.

Getz, D. (1997). Event management and event tourism. Cognizant Communication.

Getz, D. (2017). Developing a framework for sustainable event cities. Event Management, 21, 575-591. https:// doi.org/10.3727/152599517X15053272359031

Getz, D., \& Page, S. J. (2016). Progress and prospects for event tourism research. Tourism Management, 52, 593631. https://doi.org/10.1016/j.tourman.2015.03.007

Gibson, C., \& Connell, J. (2015). The role of festivals in drought-affected Australian communities. Event Management, 19(4), 445-459. https://doi.org/10.3727/15259 $9515 X 14465748512560$

Gibson, C. R., \& Wong, C. (2011). Greening rural festivals: Ecology, sustainability and human-nature relations. In C. R. Gibson \& J. Connell (Eds.), Festival places: Revitalising rural Australia (pp. 92-105). Channel View Publications.

Global Reporting Initiative. (2012). GRI Sustainability reporting guidelines \& event organizers sector supplement. https://www.globalreporting.org/search/?query=event

Global Reporting Initiative. (2015). G4 sustainability reporting guidelines. https://www.globalreporting.org/ standards/download-the-standards/

Gration, D., Arcodia, C., Raciti, M., \& Stokes, R. (2011). The blended festivalscape and its sustainability at nonurban festivals. Event Management, 15, 343-359. https:// doi.org/10.3727/152599511X13175676722564

Harris, R. (2014). The role of large-scale sporting events in host Community education for sustainable development: 
An exploratory case study of the Sydney 2000 Olympic Games. Event Management, 18, 207-230. https://doi.org/ $10.3727 / 152599514 X 13989500765600$

Helfat, C. E., \& Peteraf, M. A. (2003). The dynamic resource-based view: Capability lifecycles. Strategic Management Journal, 24(10), 997-1010. https://doi. org/10.1002/smj.332

Hindley, T., \& Buys, P. (2012). Integrated reporting compliance with the global reporting initiative framework: An analysis of the South African mining industry. International Business \& Economics Research Journal, 11(11), 1249-1260. https://doi.org/10.19030/iber.v11i11.7372

Hitchings, R., Browne, A., \& Jack, T. (2018). Should there be more showers at the summer music festival? Studying the contextual dependence of resource consuming conventions and lessons for sustainable tourism. Journal of Sustainable Tourism, 26(3), 496-514. https://doi.org/10. 1080/09669582.2017.1360316

Hvenegaard, G. T. (2011). Potential conservation benefits of wildlife festivals. Event Management, 26, 373-386. https://doi.org/10.3727/152599511X13175676722645

Isil, O., \& Hernke, M. T. (2017). The triple bottom line: A critical review from a transdisciplinary perspective. Business Strategy \& The Environment, 26, 1235-1251. https://doi.org/10.1002/bse.1982

Jepson, A., \& Stadler, R. (2017). Conceptualizing the impact of festival and event attendance upon family quality of Life. Event Management, 21, 47-60. https://doi.org/10. 3727/152599517X14809630271078

Jiang, J., \& Schmader, S. W. (2014). Event management education and professionalism: The view from the trenches. Event Management, 18(1), 25-37. https://doi.org/10.372 7/152599514X13883555341814

Kaplanidou, K., Jordan, J. S., Funk, D., \& Ridinger, L. L. (2012). Recurring sport events and destination image perceptions: Impact on active sport tourist behavioral intentions and place attachment. Journal of Sport Management, 26, 237-248. https://doi.org/10.1123/jsm.26.3.237

Kristandl, G., \& Bontis, N. (2007). Constructing a definition for intangibles using the resource-based view of the firm. Management Decision, 45(9), 1510-1524. https:// doi.org/10.1108/00251740710828744

Kwiatkowski, G. (2016). Economic impact of event attendees' spending on a host region: A review of the research. Event Management, 20, 501-515. https://doi.org/10.372 7/152599516X14745497664398

Kwiatkowski, G., \& Oklevik, O. (2017). Primary economic impact of small-scale events. Event Management, 21, 269-280. https://doi.org/10.3727/152599517X14942648 527509

Laing, J., \& Mair, J. (2015). Music festival social inclusion The festival organizers' perspective. Leisure Sciences, 37, 252-268. https://doi.org/10.1080/01490400.2014.9 91009

Lampel, J., Nadavulekere, S., \& Rawat, A. (2013). The impact of reputational resources on event performance in international film festivals. American Journal of Management, 13(2), 9-21.
Larson, M., Getz, D., \& Pastras, P. (2015). The legitimacy of festivals and their stakeholders: Concepts and propositions. Event Management, 19(2), 159-174. https://doi. org/10.3727/152599515X14297053839539

Lawton, L. J. (2009). Birding festivals, sustainability and tourism. Journal of Travel Research, 48(2), 259-267. https://doi.org/10.1177\%2F0047287509332330

Lawton, L. J., \& Weaver, D. B. (2015). Using residents' perceptions research to inform planning and management for sustainable tourism: A study of the Gold Coast Schoolies Week, a contentious tourism event. Journal of Sustainable Tourism, 23(5), 660-682. https://doi.org/10. 1080/09669582.2014.991398

Leonidou, L. C., Leonidou, C. N., Fotiadis, T. A., \& Zeriti, A. (2013). Resources and capabilities as drivers of hotel environmental marketing strategy: Implications for competitive advantage and performance. Tourism Management, 35, 94-110. https://doi.org/10.1016/j. tourman.2012.06.003

Luonila, M., \& Johansson, T. (2015). The role of festivals and events in the regional development of cities: Cases of two Finnish cities. Event Management, 19(2), 211-226. https://doi.org/10.3727/152599515X14297053839656

Ma, S.-C., Egan, D., Rotherham, I., \& Ma, S.-M. (2011). A framework for monitoring during the planning stage for a sports mega-event. Journal of Sustainable Tourism, 19(1), 79-96. https://doi.org/10.1080/09669582.2010. 502576

Maguire, K., \& Hanrahan, J. (2017). Assessing the economic impact of event management in Ireland: A local authority planning perspective. Event Management, 21, 333-346. https://doi.org/10.3727/152599517X14942648527545

Mair, J., \& Laing, J. (2012). The greening of music festivals: Motivations, barriers and outcomes. Applying the Mair and Jago model. Journal of Sustainable Tourism, 20(5), 683-700. https://doi.org/10.1080/09669582.2011. 636819

Mair, J., \& Laing, J. H. (2013). Encouraging pro-environmental behavior: The role of sustainability-focused events. Journal of Sustainable Tourism, 21(8), 11131128. https://doi.org/10.1080/09669582.2012.756494

Merrilees, B., \& Marles, K. (2011). Green business events: Profiling through a case study. Event Management, 15, 361-372. https://doi.org/10.3727/152599511X13175676 722609

Michelini, L., Iesevoli, G., \& Theodoraki, A. (2017). Event venue satisfaction and its impact on sponsorship outcomes. Event Management, 21, 319-331. https://doi. org/10.3727/152599517X14942648527536

Milne, M. J., \& Gray, R. (2012). W(h)ither ecology? The triple bottom line, the Global Reporting Initiative, and corporate sustainability reporting. Journal of Business Ethics, 118(1), 13-29. https://doi.org/10.1007/s10551012-1543-8

Misener, L., \& Mason, D. (2006). Creating community networks. Can sporting events offer meaningful sources of social capital? Managing Leisure, 11(1), 39-56. https:// doi.org/10.1080/13606710500445676 
Moise, D. (2015). Events strategies to increase competitiveness by the organizations that communicate through events. International Journal of Economic Practices and Theories, 5(3), 328-333. http://ijept. eu/index.php/ijept/article/view/Events_strategies_ to_increase_competitiveness_by_the_organizat/pdf_ 124

Musgrave, J., \& Woodward, S. (2016). Ecological systems theory approach to corporate social responsibility: Contextual perspectives from meeting planners. Event Management, 20, 356-381. http://dx.doi.org/10.3727/152599 $516 \times 14682560744712$

Neuman, W. L. (2003). Social research methods (5th ed.). Prentice Hall.

Newbert, S. L. (2007). Empirical research on the resourcebased view of the firm: An assessment and suggestions for future research. Strategic Management Journal, 28(2), 121-146. https://doi.org/10.1002/smj.573

Newbert, S. L. (2008). Value, rareness, competitive advantage, and performance: A conceptual level empirical investigation of the resource-based view of the firm. Strategic Management Journal, 29(7), 745-768. https:// doi.org/10.1002/smj.686

Nordvall, A. (2016). Organizing periodic events: A case study of a failed Christmas Market. Scandinavian Journal of Hospitality \& Tourism, 16(4), 442-460. https:// doi.org/10.1080/15022250.2015.1113142

Pernecky, T. (2015). Sustainable leadership in event management. Event Management, 19, 109-121. https://doi. org/10.3727/152599515X14229071393188

Pino, G., Peluso, A. M., Del Vecchio, P., Ndou, V., Passiante G., \& Guido, G. (2019). A methodological framework to assess social media strategies of event and destination management organizations. Journal of Hospitality Marketing \& Management, 28(2), 189-216. https://doi.org/ $10.1080 / 19368623.2018 .1516590$

Ployhart, R. E., \& Moliterno, T. P. (2011). Emergence of the human capital resource: A multilevel model. Academy of Management Review, 36(1), 127-150.

Rambaud, A., \& Richard, J. (2015). The "triple depreciation line" instead of the "triple bottom line": Towards a genuine integrated reporting. Critical Perspectives on Accounting, 33, 92-116. https://doi.org/10.1016/j.cpa. 2015.01.012

Reid, S., \& Ritchie, B. (2011). Risk management: Event managers' attitudes, beliefs, and perceived constraints. Event Management, 15, 329-341. https://doi.org/10.3727/ $152599511 X 13175676722528$

Saeed, M. M., \& Arshad, F. (2012). Corporate social responsibility as a source of competitive advantage: The mediating role of social capital and reputational capital. Journal of Database Marketing and Customer Strategy
Management, 19(4), 219-232. https://doi.org/10.1057/ dbm.2012.19

Schulenkorf, N., \& Schlenker, K. (2017). Leveraging sports events to maximize community benefits in low- and middle-income countries. Event Management, 21, 217231. https://doi.org/10.3727/152599517X14878772869 766

Simons, I. (2017). The practices of the eventful city: The case of Incubate Festival. Event Management, 21, 593-608. https://doi.org/10.3727/152599517X15053272359059

Takata, H. (2016). Effects of industry forces, market orientation, and marketing capabilities on business performance: An empirical analysis of Japanese manufacturers from 2009 to 2011. Journal of Business Research, 69(12), 5611-5619. https://doi.org/10.1016/j.jbusres.2016.03.068

Testa, M. R., \& Metter, M. (2017). Assessing economic impact as a means for event efficacy: A proposed model and case study. Event Management, 21, 61-70. https:// doi.org/10.3727/152599517X14809630271113

Toppinen, A., \& Korhonen-Kuri, K. (2013). Global Reporting Initiative and social impact in managing corporate responsibility: A case study of three multinationals in the forest industry. Business Ethics: A European Review, 22(2), 202-217. https://doi.org/10.1111/ beer. 12016

Werner, K., Griese, K.-M., \& Hogg, J. (2017). Service dominant logic as a new fundamental framework for analyzing event sustainability: A case study from the German meetings industry. Journal of Convention \& Event Tourism, 18(4), 318-343. https://doi.org/10.1080/15470148. 2017.1365670

Wernerfelt, B. (1984). A Resource-based view of the firm. Strategic Management Journal, 5(2), 171-180. https:// doi.org/10.1002/smj.4250050207

Winter, S. G. (2003). Understanding dynamic capabilities. Strategic Management Journal, 24(10), 991-995. https:// doi.org/10.1002/smj.318

Wong, I. A., Wan, Y. K. P., \& Qi, S. (2015). Green events, value perceptions, and the role of consumer involvement in festival design and performance. Journal of Sustainable Tourism, 23(2), 294-315. https://doi.org/10.1080/ 09669582.2014.953542

Wright, P. M., \& McMahan, G. C. (2011). Exploring human capital: Putting human back into strategic human resource management. Human Resource Management Journal, 21(2), 93-104. https://doi.org/10.1111/j.17488583.2010.00165.x

Ziakas, V., \& Boukas, N. (2016). The emergence of "smallscale" sports events in "small island" developing states: Towards creating sustainable outcomes for island communities. Event Management, 20, 537-563. http://doi. org/10.3727/152599516X14745497664479 
Copyright of Event Management is the property of Cognizant, LLC and its content may not be copied or emailed to multiple sites or posted to a listserv without the copyright holder's express written permission. However, users may print, download, or email articles for individual use. 